\title{
EFISIENSI SISTEM PEMANASAN AIR DENGAN PENERAPAN SELUBUNG BERTINGKAT PADA PERFORATED BURNER
}

\author{
Agung Sugeng Widodo, Francisca Gayuh Utami Dewi \\ Jurusan Teknik Mesin Universitas Brawijaya \\ J. MT. Haryono 167, Malang, 65145 \\ Telp. : (0341) 554291. Fax : (0341) 554291 \\ E-mail : agung_sw@ub.ac.id
}

\begin{abstract}
One of the causes of inefficiency in the heating system by using a gas stove is radiation heat transfer. The application of stratified sheath is expected to reduce the heat loss. In this study an investigation conducted on a gas stove type perforated burner, by adding a stratified sheath. The parameters such as energy absorbed by water and energy produced by fuel are used to measure the performance of the heating system. The fuel is liquid petroleum gas (LPG) with a composition of $50 \%$ butane and $50 \%$ propane. The results show that the application stratified sheath on perforated burner at 0,0125 liter / sec has an average efficiency of 53,2\% with the time required to boil 1,5 liters of water for 670 seconds, 36 seconds faster for the case perforated burner without stratified sheath and 80 seconds faster than conventional burner cases

Keywords: stratified sheath, perforated burner, efficiency, radiation
\end{abstract}

\section{PENDAHULUAN}

Efisien sebuah sistem pemanasan menjadi sesuatu yang krusial mengingat akan kelangkaan energi dewasa ini. Kompor gas konvensional dalam kontek efisiensi energi merupakan object yang perlu untuk ditingkatkan performansinya dalam rangka mengatasi permasalah di atas. [1-2]

Kompor gas konvensional merupakan sebuah aplikasi proses pembakaran yang dikarakteristikkan dengan sebuah nyala api bebas (free flame), dimana nyala api terbentuk akibat reaksi pembakaran dan dengan adanya efek gaya apung maka arah panas akan menuju ke atas. Proses pembakaran dengan kondisi di atas akan membuat proses perpindahan panas didominasi oleh perpindahan panas konveksi dan radiasi. Selain itu, perubahan terhadap bentuk geometri nyala api juga berpengaruh terhadap proses pembakaran itu sendiri.

Berkaitan dengan kondisi bentuk nyala api bebas pada kompor gas, berbagai penelitian mengenai kompor gas konvensional telah dilakukan. Aplikasi selubung pada sebuah kompor gas konvensional menunjukkan selisih $2,6 \%$ dibandingkan dengan kompor gas konvesional tanpa selubung [3]. Pengaturan jarak selubung dengan beban pemanasan juga menunjukkan pengaruh terhadap efisiensi pemanasan, dimana jarak antara selubung dan beban tertentu akan menghasilkan sebuah efisiensi tertinggi. Pengaturan jarak pada kondisi di atas akan mengoptimumkan pelepasan perpindahan panas konveksi dan konveksi yang berlangsung secara simultan [4]. Penerapan nyala api radiant juga dilakukan guna untuk meningkatkan efisiensi sekaligus penurunan emisi gas buang [5-8].

Penambahan sebuah material padat diantara selubung dan beban pemanasan berupa grid juga telah dilakukan [9]. Proses tersebut dilakukan untuk menggenerasi turbulensi pada aliran setelah keluar grid. Hasilnya menunjukkan baik secara kuantitas maupun visualisasi bahwa efisiensi maksimal naik sekitar $5 \%$ dibandingkan dengan kompor gas konvensional tanpa menggunakan grid. Pemakaian grid ternyata selain menggenerasi turbulensi pada aliran keluar grid (berpengaruh pada proses pencampuran antara bahan bakar dan udara), juga memperbesar distribusi temperatur pada luasan kontak api ke beban pemanasan. Hal tersebut di tunjukkan dengan semakin lebarnya luasan api ketika menyentuh beban dibandingkan dengan tanpa menggunakan grid. Distribusi temperatur yang besar diharapkan akan memperbesar flux 
panas yang diterima oleh beban dari sistem pemanas.

Penambahan selubung keramik dan penambahan grid pada kompor gas konvensional telah membuktikan adanya peningkatan efisiensi pada sistem pemanasan. Dari latar belakang tersebut akan dilakukan investigasi mengenai pengaruh penambahan selubung berlubang dua lapis diantara burner dan beban pemanasan guna mencari karakterisik nyala api dan efisiesi sistem pemanasan air dengan menggunakan kompor gas jenis perforated.

\section{METODOLOGI PENELITIAN}

Instalasi penelitian untuk mencari karakteristik sistem pemanasan air dengan penerapan selubung bertingkat pada perforated burner dapat dilihat pada gambar 1.Perforated burner didesain dengan 3 lapisan dengan uraian 10 lubang pada bagian dalam, 20 lubang pada lapisan kedua dan 30 lubang pada lapis terluar, sehingga jumlah total lubang ada 60 lubang. Selubung berlubang kemudian di letakkan di antara lapis lapis tadi. Beban dibuat dari aluminium dengan diameter $20 \mathrm{~cm}$ dan
Pertamina, dengan komposisi $50 \%$ butana dan $50 \%$ propana. Flow meter dengan merk Zyia dengan range pengukuran $0,3-3,0 \mathrm{Nl} / \mathrm{min}$. Termometer alkohol tipe AL-30100-010 dengan range pengukuran $-10^{\circ} \mathrm{C}-110^{\circ} \mathrm{C}$ digunakan untuk mengukur temperatur air dalam beban.

Konsep efisiensi pada penelitian ini adalah nilai energi yang diserap oleh air di dalam loading (massa loading tidak di hitung) dibagi dengan nilai energi yang hasilkan oleh bahan bakar LPG seperti terlihat pada persamaan 1 .

$\eta=\frac{m_{a} C_{p a} \Delta T}{m_{f} L H V_{f}} \times 100 \%$

dimana $m_{a}$ adalah massa air, $C_{p a}$ adalah panas jenis air dan $\Delta T$ adalah perbedaan awal dan akhir temperatur pengukuran, $m_{f}$ adalah massa bahan bakar, dan $L H V_{f}$ adalah nilai kalor bahan bakar. Metode perhitungan efisiensi dan panas radiasi dapat di lihat di dalam [Widodo, 2016].

Kondisi penelitian, nilai kalor bahan bakar LPG serta spesifikasi bahan penelitian lainnya dapat dilihat pada tabel 1.

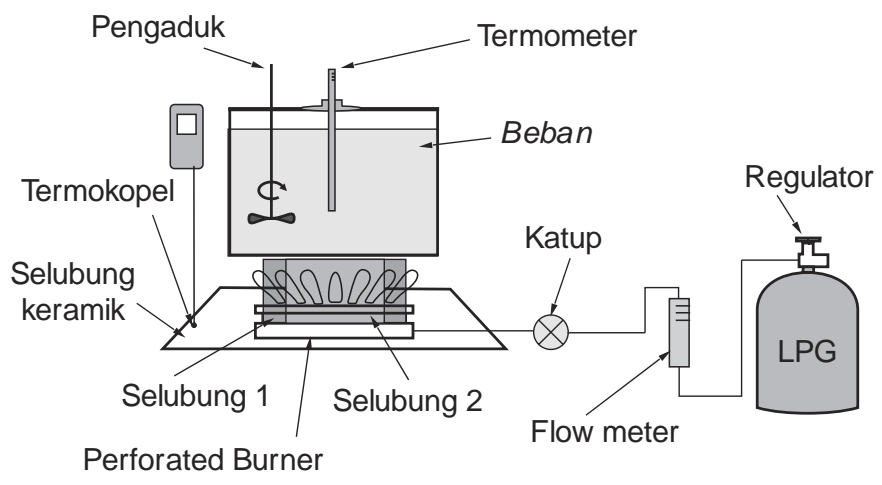

Gambar 1. Skema instalasi penelitian

berat \pm 200 gram. Beban dilengkapi dengan sebuah penutup dengan tujuan agar proses penguapan air tidak keluar beban, sehingga massa total dari air dalam beban konstan. Selain itu beban juga dilengkapi dengan sebuah pengaduk untuk membuat distribusi temperatur di dalam beban merata, sehingga temperatur yang dibaca oleh termometer akan mewakili jumlah energi yang di serap oleh air. Bahan bakar yang di gunakan adalah LPG produksi
Pengambilan temperatur awal air disesuaikan dengan kondisi lokal atmosfer pada malam hari sekitar pukul 8.00 WIB dengan fluktuasi $\pm 1^{\circ} \mathrm{C}$ dan temperatur akhir air pada kondisi mendidih adalah $92^{\circ} \mathrm{C}$ akibat dari topografi lokasi penelitian yang berada di 


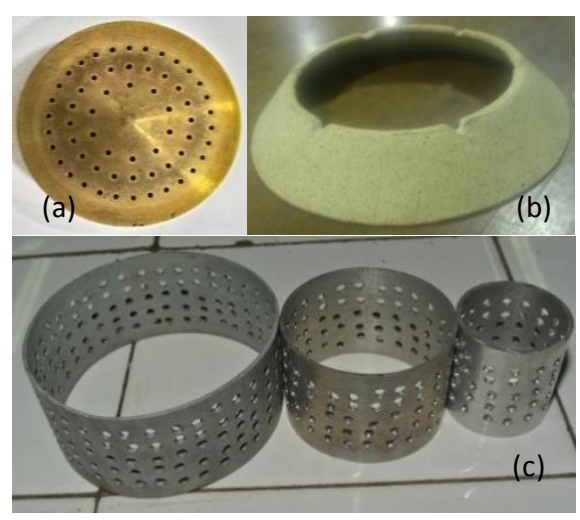

Gambar 2. Perforated burner (a) ; selubung keramik (b) ; selubung bertingkat (c) yang digunakan dalam penelitian

ketinggian $\pm 476 \mathrm{~m}$ dari permukaan laut. Kondisi mendidih pada penelitian ini asumsikan sebagai kondisi dimana timbul gelembung air diseluruh permukaan dasar beban $( \pm 50 \%$ permukaan dasar beban). Hal ini dilakukan supaya pembacaan temperatur akhir tidak berbeda atau seragam sehingga jumlah energi yang diserap oleh air sama dalam setiap perlakukan. Panas jenis air yang digunakan adalah panas jenis air rata-rata pada temperatur pendidihan. Nilai LHV bahan bakar yang digunakan juga merupakan proporsional komposisi dari bahan bakar LPG sebesar $46,4 \mathrm{MJ} / \mathrm{kg}$.

Tabel 1 Kondisi penelitian.

\begin{tabular}{|c|c|}
\hline Kondisi Penelitian & Nilai \\
\hline Massa air & $1,5 \mathrm{~kg}$ \\
\hline Temperatur awal air & $25^{\circ} \mathrm{C}$ \\
\hline Temperatur akhir air & $92^{\circ} \mathrm{C}$ \\
\hline Panas jenis air & $4,196 \mathrm{~J} / \mathrm{kg}{ }^{\circ} \mathrm{C}$ \\
\hline Debit $(\mathrm{Q})$ gas LPG & $45 \mathrm{l} / \mathrm{h}$ \\
\hline Massa jenis ( $\rho$ ) gas LPG & $0,0021 \mathrm{~kg} / \mathrm{L}$ \\
\hline LHV gas propana & $46,1 \mathrm{MJ} / \mathrm{kg}$ \\
\hline LHV gas butana & $46,5 \mathrm{MJ} / \mathrm{kg}$ \\
\hline \multirow{2}{*}{ Komposisi gas LPG } & $50 \%$ propana \\
\cline { 2 - 2 } & $50 \%$ butana \\
\hline
\end{tabular}

\section{HASIL DAN PEMBAHASAN}

Grafik efisiensi persatuan waktu pada penelitian ini dapat dilihat di gambar 3. Seperti terindikasi pada grafik tersebut, terlihat pada awal proses pemanasan air, efisiensi kompor gas dengan penambahan selubung bertingkat (KPS) terlihat lebih rendah dibandingkan dengan kompor konvensional (KK) maupun kompor dengan tipe perforated (KP).

Hal tersebut disebabkan karena adanya penambahan selubung bertingkat akan mengakibatkan panas yang dihasilkan pada proses pembakaran pada awal awal proses pemanasan akan terserap oleh selubung bertingkat, hal ini karena perbedaan temperatur yang relatif tinggi. Tetapi seiring dengan bertambahnya waktu dan perbedaan temperatur antara material diantara selubung dan beban, maka efisiensi sistem pemanasan meningkat dan mencapai puncaknya. Pada akhir pemanasan, efisiesi cenderung menurun karena perbedaan temperatur yang relatif kecil, sehingga proses perpindahan panas dari api atau gas hasil pembakaran menjadi lebih kecil. Justru pada kondisi seperti inilah, fungsi selubung bertingkat terindikasi lebih baik untuk menahan perpindahan panas radiasi dari nyala api. Selain itu, penambahan selubung bertingkat terlihat memicu terjadinya turbulensi. Dimana turbulensi tersebut bisa dihasilkan dari kekhasan permukaan selubung yang dilalui aliran maupun dari pertukaran gas diantara lubang selubung.

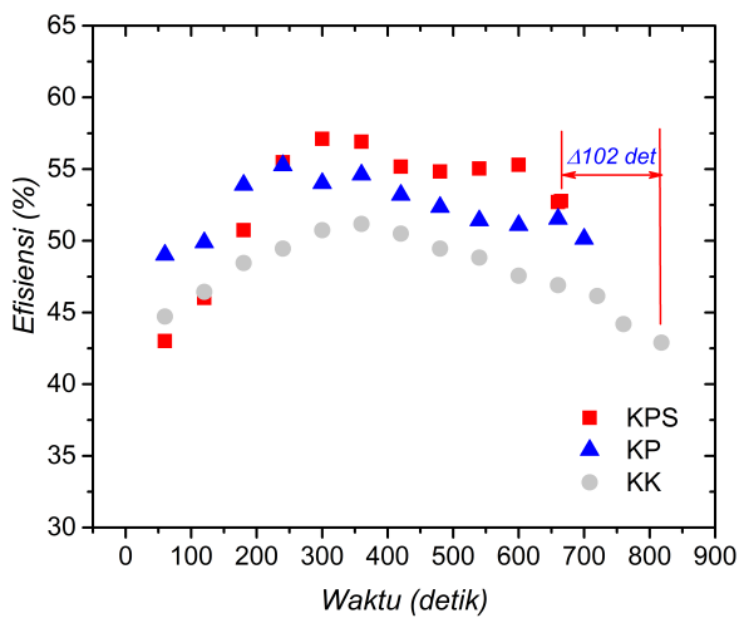

Gambar 3. Efisiensi per satuan

Efisien maksimal pada KPS adalah $57 \%$ lebih tinggi $1,7 \%$ dari KP dan $5,8 \%$ dari KK. 
Proses pendidihan pada ketiga kasus diatas juga menunjukkan perbedaan waktu didih. Waktu didih pada KPS adalah 670 detik, lebih cepat 180 detik dari KK dan 26 detik dari KP. 180 detik waktu pendidihan pada kontek penelitian ini akan setara dengan penghematan energi sebesar $218,7 \mathrm{~kJ}$.

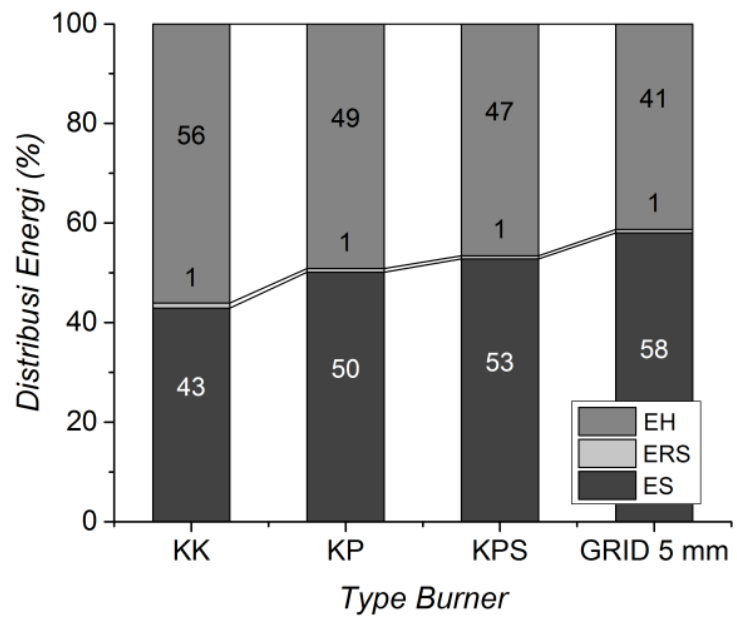

Gambar 4. Distribusi Energi

Gambar 4 menunjukan distribusi energi yang terjadi pada sebuah sistem pemanasan pada berbagai kasus. Di dalam grafik 4 pula diperlihatkan hasil penelitian oleh Widodo [2016] tentang pengaplikasian grid setebal 5 $\mathrm{mm}$ di dalam sistem pemanasan digunakan sebagai pembanding. Energi yang diserap air (ES) pada kasus KK hanya sebesar $43 \%$ dari total energi yang dihasilkan oleh bahan bakar. Sedang penggunaan burner perforated berhasil meningkatkan jumlah energi yang di serap sebesar $7 \%$ dan penggunaan selubung bertingkat mempunyai jumlah energi yang diserap air sebesar $53 \%$.
Terlihat bahwa geometri dan warna nyala api berbeda untuk setiap kasus. Efisiensi KK relatif lebih rendah jika dibandingkan dengan KP dan KPS karena posisi nyala api yang terlalu ke pinggir dari pusat beban pemanasan. Hal menyebabkan distribusi temperatur pada beban hanya terpusat pada bagian tepi beban, sehingga penyerapkan panas dari gas atau nyala api relatif tidak besar jika dibandingkan dengan KPS maupun KP. Atau dengan kata lain, waktu tinggal pemanasan relatif lebih kecil jika dibandingkan dengan KPS dan KP karena gas panas relatif lebih cepat keluar dalam bentuk konveksi maupun radiasi. Bentuk dari kasus KPS terlihat lebih turbulen dibandingkan dengan kasus lainnya. Turbulensi dan bentuk api yang melebar dari pusat beban menuju ke pinggir menyebabkan distribusi temperatur penyerapan panas menjadi labih merata. Hal ini di buktikan dengan tempratur ruang bakar yang relatif lebih besar pada kasus KPS dibandingkan dengan kasus lainnya

\section{KESIMPULAN}

Pada penelitian ini sebuah investigasi untuk mengukur performansi sebuah sistem pemanasan dengan penerapan selubung bertingkat telah dilakukan. Dari diskusi dan pembahasan dapat diambil kesimpulan sebagai berikut.

1.Pada sebuah massa alir konstan sebesar $0.0125 \mathrm{l} / \mathrm{s}$ bahan bakar LPG, efisiensi maksimal sebuah sistem pemanasan diperoleh pada kasus KPS yaitu sebesar grid dengan tebal $5 \mathrm{~mm}$. Efisiensi tertinggi yang diperoleh adalah $53.2 \%$ lebih besar dibandingkan dengan sistem pemanasan pada kasus KK dan KP.

2.Penerapan selubung bertingkat pada perforated burner dapat memicu turbulensi

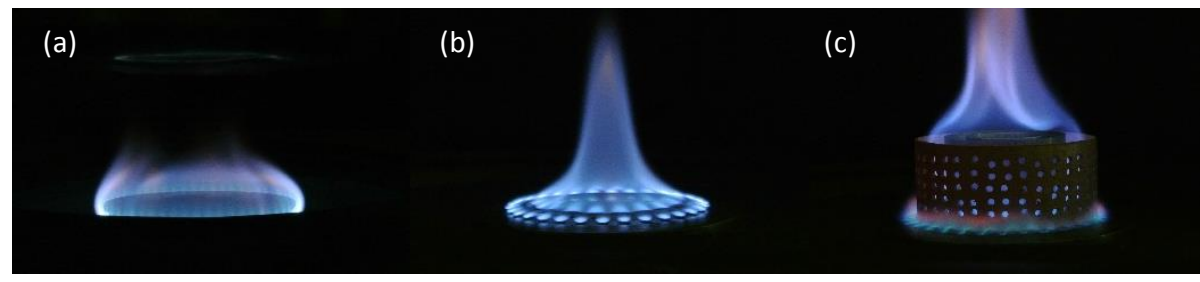

Gambar 5. Visualisasi api pada kasus KK (a); KP (b); KPS.

Gambar 5 menunjukan hasil visualisasi dari sistem pemanasan pada berbagai kasus. pada nyala api yang mengakibatkan temperatur dan proses penyerapan panas nyala beban menjadi lebih baik. 


\section{UCAPAN TERIMA KASIH}

Penulis mengucapkan banyak terima kasih kepada Fakultas Teknik Universitas Brawijaya atas biaya DIPA yang diberikan dengan nomor kontrak No.15/UN.10.6/PG/2017 sehingga penelitian ini dapat terselesaikan. Ucapkan terima kasih pula penulis sampaikan kepada saudara Muhammad Kurniawan atas bantuan dalam pelaksanaan penelitian ini serta semua pihak yang tidak dapat penulis sebutkan satu persatu.

\section{DAFTAR PUSTAKA}

[1] Anonymous. (2012). Conversion Oil to Gas, Reduce Subsidy for Long Term, Ministry and Mineral Resources of Republic of Indonesia.

[2] Lontoh L., et al., 2015, Indonesia Energy Subsidy Review, International Institute for Sustainable Development, Issue 1. Volume 2. March 2015.

[3] Widiandra, P., \& Widodo, A.S. (2014), Effect of Materials Stove Cover to the Efficiency of Gas Stove Water Boiling
System, Jurnal Rekayasa Mesin, Vol.5, No.3, 291-295, Brawijaya University.

[4] Widodo, A.S., (2015) Jarak Optimum Panci Terhadap Selubung Pada Efisiensi Sistem Pemanasan Air, Jurnal Rekayasa Mesin Vol.6, No.1 Tahun 2015:69-73

[5] Yu, B. et al., (2013), Combustion characteristics and thermal efficiency for premixed porous-media types of burners, Energy 53, pp. 343-350.

[6] Muthukumar, P. et al. (2011), Performance analysis of porous radiant burners used in LPG cooking stove, International Journal of Energy and Environment Volume 2, Issue 2, 2011 pp.367-374

[7] Jugjai S, \& Rungsimuntuchart N. (2002), High efficiency heat-recirculating domestic gas burners. Experimental Thermal and Fluid Science ;26(5):581-92.

[8] Pantangi V.K., et al., Studies on porous radiant burners for LPG cooking applications. Energy;36:6074-80

[9] Widodo, A.S., (2016)., Peningkatan Efisiensi Sistem Pemanasan dengan Penambahan Grid pada Perforated Burner. 